\title{
Use of adjuvant chemotherapy in resected non-small cell lung cancer in real-life practice: a systematic review of literature
}

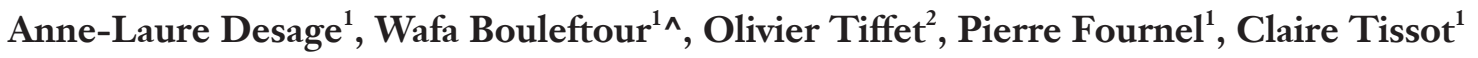 \\ ${ }^{1}$ Department of Medical Oncology, Lucien Neuwirth Cancerology Institute, Saint Priest en Jarez, France; ${ }^{2}$ Department of General Surgery, Saint \\ Etienne Hospital, Saint-Etienne, France \\ Contributions: (I) Conception and design: All authors; (II) Administrative support: None; (III) Provision of study materials or patients: None; (IV) \\ Collection and assembly of data: AL Desage, W Bouleftour; (V) Data analysis and interpretation: AL Desage, W Bouleftour; (VI) Manuscript \\ writing: All authors; (VII) Final approval of manuscript: All authors. \\ Correspondence to: Dr. Wafa Bouleftour. Department of Medical Oncology, Lucien Neuwirth Cancerology Institute, 108 Bis Avenue Albert Raimond, \\ Saint Priest en Jarez 42270, France. Email: wafa.bouleftour@icloire.fr.
}

Background: Adjuvant chemotherapy (AC) is recommended since 2004 for patients with a completely resected non-small cell lung cancer (NSCLC). Indeed, several randomized clinical trials have demonstrated an improved survival for patients treated with adjuvant cisplatin-based regimen than surgery alone. In these large clinical trials, patients were well selected and fit to receive AC. As the benefit of AC was estimated at $5.4 \%$ of 5 -year overall survival (OS), it seems important to evaluate AC use in a less selected population. In particular, elderly patients were underrepresented in large randomized clinical trials. Furthermore, other confounding factors might limit AC efficacy in real-life practice such as the delay of chemotherapy initiation following lung surgery or the number of AC cycles received. Therefore, the aim of this systematic review is to summarize the state of the literature on AC use in current clinical practice.

Methods: A systematic assessment of literature articles and reviews on AC use in real-life practice was performed by searching in several relevant database including Medline, Google Scholar and Cochrane Library following PICOS (i.e., Population, Intervention, Comparison, Outcomes, Study design) eligibility criteria and PRISMA guidelines. Among the 1,957 results obtained with the request formulated on these research database, 56 relevant articles on AC use in non-trial setting were selected and included in the results section.

Results: This systematic literature review highlights the lack of literature on AC use in real-life practice as most of these studies were retrospective. Interestingly, a delayed AC-mostly due to postoperative complications-was better than surgery alone. Furthermore, AC was less purposed to elderly patients, despite retrospective studies outlined that this therapeutic option could be benefit in this specific population as for younger patients. In real-life practice, AC was also often incomplete due to adverse events, but dose reduction or omission was not always associated with an inferior survival. In non-trial setting, number of AC cycles delivered, dose reduction or omission is quite similar to randomized clinical trials.

Discussion: Nowadays, AC is part of the therapeutic strategy used in completely resected NSCLC. In a population of less selected patients, this systematic literature review shows that AC can be used safely and efficiently, especially in elderly patients. As well, delayed AC seems effective. Finally, the place of immunotherapy and targeted therapies have to be precised in the future as well as biomarkers to better select patients that would response to chemotherapy.

Keywords: Adjuvant chemotherapy (AC); non-small cell lung cancer (NSCLC); stage IIA to IIIA; $8^{\text {th }}$ TNM classification

Submitted Jul 07, 2021. Accepted for publication Nov 01, 2021.

doi: $10.21037 /$ tlcr-21-557

View this article at: https://dx.doi.org/10.21037/tlcr-21-557

\footnotetext{
^ ORCID: 0000-0002-8485-9386.
} 


\section{Introduction}

According to 2018 Global Cancer Observatory (GLOBOCAN), lung cancer represents $11.6 \%$ of the number of new cases of cancer worldwide and is responsible of $18.4 \%$ number of deaths from cancer (1). Adjuvant chemotherapy (AC) for completely resected non-small cell lung cancer (NSCLC) has been implemented at the beginning of the 2000s.

Several randomized clinical trials conducted at the beginning of 2000 have demonstrated an improved survival for patients treated with cisplatin-based $\mathrm{AC}$ after complete surgical resection for stage IIA-IIIA NSCLC compared to surgery alone (2-4). The IALT trial (The International Adjuvant Lung Cancer Trial Collaborative Group) was the first and the largest AC trial which demonstrated a statistically significant improvement in overall survival (OS) for patients treated with cisplatin-based AC. Indeed, in the IALT trial which compared cisplatin-based regimen (with etoposide, vinorelbine, vinblastine or vindesine) with surgery alone, the 5 -year survival rates were $44.5 \%$ and $40.4 \%(\mathrm{P}<0.03)$ in respectively AC and surgery alone group (Table 1) (2). Likewise, JBR.10. (National Cancer Institute of Canada Clinical Trials Group and North American Intergroup Study JBR.10) and ANITA (Adjuvant Navelbine International Trialist Association) clinical trials which compared cisplatin-vinorelbine with surgery alone, demonstrated a significant benefit of AC use on OS (Table 1) $(3,4)$. The LACE meta-analysis (Lung Adjuvant Cisplatin Evaluation) included a total of 4,584 patients from five cisplatin-based adjuvant trials (i.e., IALT, JBR.10., ANITA, ALPI-EORTC and Big Lung Trial) (5). This meta-analysis confirmed the benefit of AC with a $5.4 \%$ improvement in survival at 5 years $(\mathrm{P}=0.0043)$ (Table 1). The disease-free survival (DFS) was also significantly improved with a hazard ratio of 0.8 [HR (95\% CI): $0.8(0.78-0.9)$; $\mathrm{P}<0.001]$ (5). Finally, a Cochrane review published in 2015, based on 8,447 individual data analyses showed a benefit of AC with an absolute increase in survival (4\% at 5 years) (6). Other clinical trials were conducted but failed to demonstrate a survival benefit of AC. This was the case of the ALPI trial (Adjuvant Lung Project Italy) in which patients received three cycles of mitomycin, vindesine and cisplatin (7). Similarly, the Big Lung Trial showed no benefit of cisplatinbased AC probably due to a lack of patients (8). Furthermore, the CALGB trial (Cancer and Leukemia Group B) which enrolled only patients with IB (i.e., T2N0M0) resected NSCLC failed to demonstrate a statistically significant benefit of Carboplatin-Paclitaxel AC (9). The mortality rate due to $\mathrm{AC}$ was estimated at $0.8 \%$ of the patients in the IALT (2) and JBR.10. (3) trials whereas it was about $2 \%$ in the ANITA trial (4). In the LACE meta-analysis, there were 19 chemotherapy-related deaths reported, corresponding to a $0.9 \%$ mortality rate (5) (Table 1 ).

Consequently, since these randomized clinical trials were published, AC is recommended in resected NSCLC for stage IIA to IIIA, according to the $8^{\text {th }}$ TNM classification (10-12). Of note, four cycles of cisplatin-vinorelbine (cisplatin $80 \mathrm{mg} / \mathrm{m}^{2} \mathrm{~J} 1$ and vinorelbine $30 \mathrm{mg} / \mathrm{m}^{2} \mathrm{~J} 1-\mathrm{J} 8$ ) must be preferred. Indeed, in the LACE meta-analysis, the effect of cisplatin-vinorelbine was better in terms of OS and DFS compared to other drugs combination $(\mathrm{P}=0.11$ for $\mathrm{OS}$ and $\mathrm{P}=0.07$ for DFS) (5).

In view of contradictory data, the aim of this systematic literature review is to summarize the state of literature regarding AC use in current clinical practice. Indeed, in randomized clinical trials, patients were well selected to fit chemotherapy. In the setting of real-life practice, elderly patients were not included in those clinical trials and chemotherapy was administered in a delay which did not exceed 60 days after surgery. Therefore, as AC provides a moderate benefit of $5.4 \%$ of 5 -year OS in large randomized clinical trials (5), the assessment of AC efficacy and safety profile in a less selected and more heterogeneous population is valuable. In this context, real-world evidence (RWE) would be interesting to validate whether AC provides same efficacy and safety profile as reported in large randomized clinical trials. Thus, this systematic literature review will detail the use of AC for resected NSCLC in routine clinical practice. We present the following article in accordance with the Preferred Reporting Items for Systematic Reviews and Meta-Analyses (PRISMA) 2020 reporting checklist (available at https://dx.doi.org/10.21037/tlcr-21-557).

\section{Materials and methods}

A systematic assessment of literature articles and reviews was performed by searching in several relevant database including Medline, Google Scholar and Cochrane Library, following PRISMA guidelines and PICOS (i.e., Population, Intervention, Comparison, Outcomes, Study design) eligibility criteria.

The request formulated in MEDLINE was built in the following way ("Carcinoma, non- small cell lung [MeSH Terms]" OR "resected non-small cell lung cancer [Other Terms]" OR "lung cancer [MeSH Terms]" and "adjuvant 


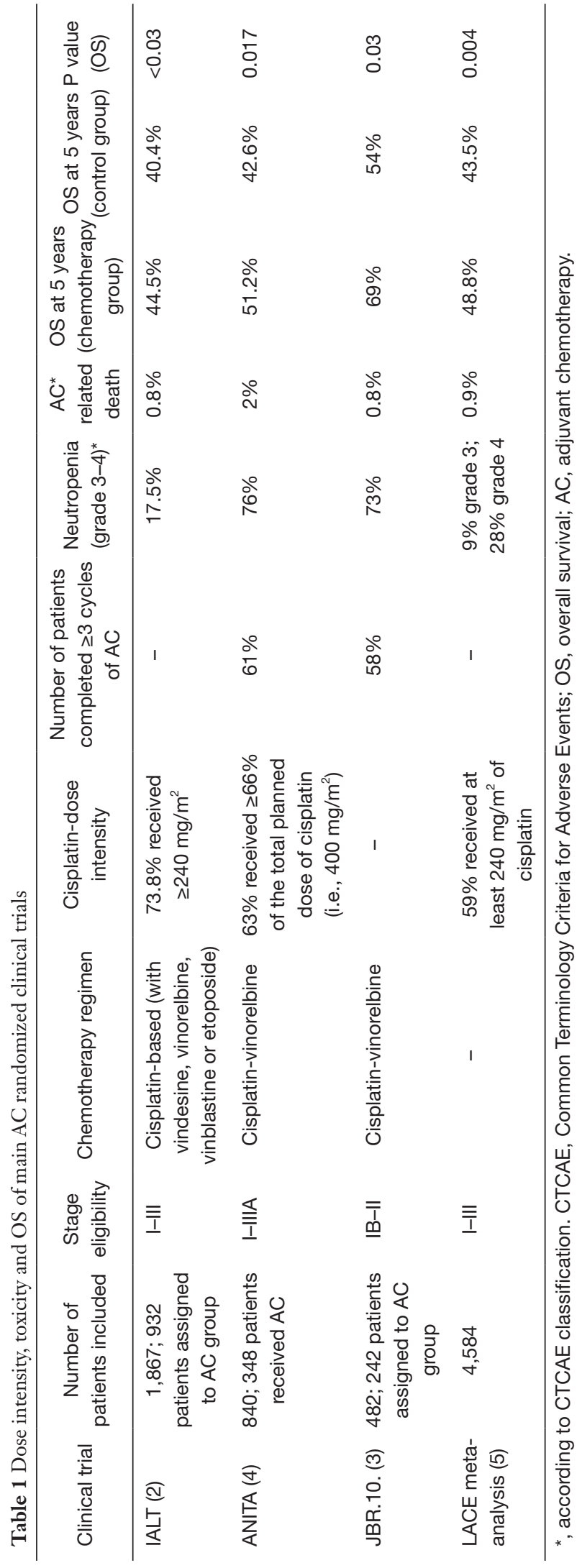

chemotherapy [MeSH Terms]" OR "delayed adjuvant chemotherapy [Other Terms]" OR "initiation of adjuvant chemotherapy [Other Terms]"). Applying this request formulation in Medline on $8^{\text {th }}$ March 2021 resulted in 3,137 results. Additional filters were applied ("years of publication from 2004 to 2021"; "language: English"; "abstracts available"; "subject: cancer"; "species: humans") which led to 1692 results. The request formulated in Cochrane Library on $29^{\text {th }}$ September 2021 was built in the following way ("non-small cell lung cancer" [Title, abstract, keyword] AND "adjuvant chemotherapy" [Title, abstract, keyword] AND "observational" [Abstract]) which led to 244 results. Applying this request formulation with additional filters on years of publication (i.e., 2004 to 2021) led to 210 results. The request formulated in Google Scholar on $30^{\text {th }}$ September 2021 was built in the following way ("adjuvant chemotherapy" AND "lung cancer" AND "real-life practice") and allowed to identify 65 results. Additional filter applied based on years of publication (i.e., 2004 to 2021) led to 55 results.

Relevant articles were selected after reading titles and abstracts by one author based on PICOS eligibility criteria (Table 2). After screening, eligible articles were either included or excluded through full-text reading by one author. The formulation request, the selection process and the eligibility of articles were critically peer-reviewed by all authors. This research allowed to select 56 relevant articles included in the results section (Figure 1).

\section{Results}

A total of 1957 titles/abstracts were screened given the search and restriction filters applied on Medline, Cochrane Library and Google Scholar database (Figure 1). This preliminary screening restricted our search to 112 potentially eligible papers that were either included or excluded through full-text reading. Overall, 56 relevant articles were selected and included in this systematic literature review (Figure 1).

Adherence to guidelines regarding $\mathrm{AC}$ administration was estimated at $59 \%$ among 99 eligible patients who underwent curative-intent lung surgery for stage IIIII NSCLC disease (13) while it was reported at $54.1 \%$ among a cohort of 14,892 patients who underwent surgical resection for $\mathrm{pN} 1$ disease (14). Barni et al. reported the main reasons for no respect to guidelines: patient's refusal (10\%), patient's clinical conditions (43\%); negative lymph node disease (17\%) and clinician's choices (13\%) (13). 
Table 2 Eligibility criteria for study selection process according to PICOS guidelines

\begin{tabular}{|c|c|c|}
\hline $\begin{array}{l}\text { PICOS } \\
\text { guidelines }\end{array}$ & Eligibility criteria & Exclusion criteria \\
\hline Patients & $\begin{array}{l}\text { Patients that underwent curative- } \\
\text { intent lung surgery for NSCLC. } \\
\text { Patients with theoretical indication of } \\
\text { AC or patients who received AC }\end{array}$ & $\begin{array}{l}\text { Patients with advanced or metastatic NSCLC were excluded } \\
\text { Articles that enrolled only patients with stage I NSCLC disease were excluded } \\
\text { Patients with other histologic sub-types (i.e., small-cell lung cancer, large cell } \\
\text { neuroendocrine lung carcinoma, carcinoid tumours, malignant pleural mesothelioma } \\
\text { and other cancers) were excluded }\end{array}$ \\
\hline Intervention & $\mathrm{AC}$ in real-life practice & $\begin{array}{l}\text { Neoadjuvant strategies and other adjuvant strategies (i.e., targeted therapies, } \\
\text { immunotherapy, other chemotherapy regimens) were excluded } \\
\text { Other studies dealing with treatments part of the multimodal strategy (i.e., surgery, } \\
\text { radiotherapy, concomitant or sequential chemotherapy) were excluded }\end{array}$ \\
\hline Comparison & $\begin{array}{l}\text { No control group defined for } \\
\text { intervention }\end{array}$ & - \\
\hline Study design & $\begin{array}{l}\text { Prospective or retrospective } \\
\text { observational studies on AC use in } \\
\text { real-life practice for resected NSCLC. } \\
\text { As the first randomized clinical trial } \\
\text { on AC was published in } 2004 \text {, study } \\
\text { eligibility criteria also included period } \\
\text { of publications from } 2004 \text { to } 2021\end{array}$ & $\begin{array}{l}\text { Randomized clinical trials and sub-group analysis on AC out of the context of real- } \\
\text { life practice were excluded } \\
\text { Reviews and meta-analysis about lung cancer and AC out of the context of real-life } \\
\text { practice were excluded } \\
\text { Articles dealing with predictive and prognostic markers in lung cancer, pre-clinical } \\
\text { studies, guidelines and case report on lung cancer were excluded }\end{array}$ \\
\hline
\end{tabular}

NSCLC, non-small cell lung cancer; AC, adjuvant chemotherapy.

In particular, concerns for AC toxicity was involved in $31 \%$ of patient's refusal (15). Consistently with previous observations, advanced age and disease progression were associated with a lower likelihood to receive AC, in 6\% cases respectively $(16,17)$. Postoperative complications (18-20) and prolonged length of stay after surgery (21) were also identified as main factors to not receive $\mathrm{AC}$ although recommended. In this context, AC use in non-trial setting will be described in the following sections according to the 56 relevant articles selected (Figure 1) through the selection process.

\section{Delay of initiation of AC in real-life practice and impact on survival}

Several barriers may impact the use of AC in non-trial setting such as patient's decision, physician and patient opinions regarding the ability to tolerate $\mathrm{AC}$ and the potential benefits outweigh the risks. As well, recovery from lung surgery and post-operative complications or prolonged length of stay in hospital might contribute to the decision and to delayed AC administration. Notably, referral to medical oncologist is also important to consider in real-life practice.

An observational study reporting patient's and physician's preferences regarding AC, using the time trade-off method, highlighted that most patients and physicians judged moderate survival benefits sufficient to make AC worthwhile after curative-intent lung surgery for a NSCLC (22). As well, the authors described patients' opinions at baseline regarding AC tolerance. Interestingly, the main symptoms expected at baseline by patients were asthenia, nausea, trouble sleeping or lack of appetite whereas main symptoms experienced at 6 months by patients were asthenia, altered sense of taste, constipation or lack of appetite (22). In clinical setting, such symptoms related to AC need to be clearly explained as they might contribute to patient's refusal to underwent AC. In line with these observations, referral to medical oncologist is of particular interest. Of note, preferred and perceived decision making roles on AC were reported as collaborative for both physicians and patients (23). Younis et al. reported that $73 \%$ patients with stage II-III NSCLC were referred to a medical oncologist (24). Consistently, referral to medical oncologist 


\section{Identification of studies via databases and registers}

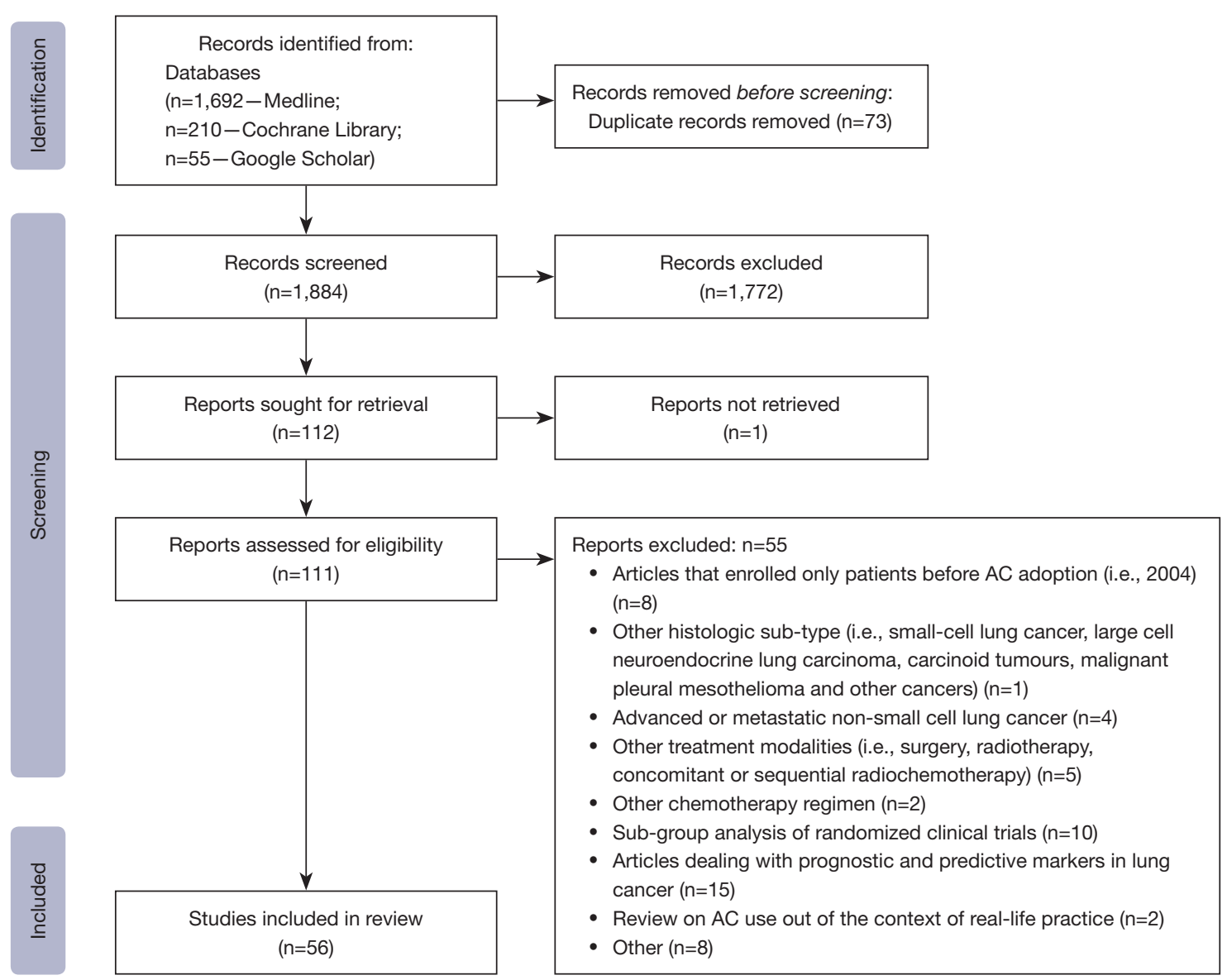

Figure 1 PRISMA 2020 flow diagram presenting the selection process for relevant articles on use of AC in real-life practice. AC, adjuvant chemotherapy.

was reported as $72 \%$ among 352 patients with stage IBIIB NSCLC (15). In another retrospective study, $44 \%$ of patients who underwent curative-intent surgery for stage I-III NSCLC were referred to medical oncologist, with a median of 29 days between surgery to medical oncologist referral (25). As well, timeline was estimated at 16 days between medical oncologist referral and consultation and 7 days between medical oncologist's consultation and AC administration (25). A shorter timeline for medical oncologist referral was significantly associated with surgeon requesting for medical oncologist referral $(\mathrm{P}=0.008)$ and presence of comorbidities ( $\mathrm{P}=0.036)$ (25). In multivariate analysis, higher likelihood of referral to medical oncologist was associated with higher stage disease (i.e., stage II/III $v s$. I), surgery (i.e., pneumonectomy) and age (i.e., younger) (24).
Of note, patient's refusal was involved in $5 \%$ cases of no referral to medical oncologist (24) while it was estimated at $18 \%(16)$ and $2 \%(26)$ in other retrospective studies. Apart from patient's refusal $(16,24,26)$, comorbidities, advanced age, postoperative complications and poor performance status (PS) were the main reason advanced by surgeons for judging patients as not fit to receive AC $(16,27)$. Likewise, altered condition after surgery was involved in $7.2 \%$ of cases for not referred to medical oncologist (26). Consistently with predictive factors associated with referral to medical oncologist (27), intermediate or high grade tumour (i.e., $v s$. low grade tumour) and higher stage disease (i.e., IIIA vs. IIA and IIB) were associated with a higher likelihood to receive AC while advanced aged, pneumonectomy, squamous cell histologic sub-type, higher 
Table 3 Median length of stay in hospital after curative-intent lung surgery in non-trial setting

\begin{tabular}{|c|c|c|c|}
\hline Study & $\begin{array}{l}\text { Number of patients } \\
\text { included }\end{array}$ & $\begin{array}{l}\text { Period of } \\
\text { recruitment }\end{array}$ & Length of stay in hospital after surgery \\
\hline $\begin{array}{l}\text { Wright et al., } \\
2008,(30)\end{array}$ & 4,979 & $\begin{array}{l}\text { Retrospective } \\
(2002 \rightarrow 2006)\end{array}$ & Median length of stay: 6 days \\
\hline $\begin{array}{l}\text { Massard et al., } \\
2009,(18)\end{array}$ & 219 & $\begin{array}{l}\text { Retrospective } \\
(2004 \rightarrow 2005)\end{array}$ & Median length of stay: 8 days (range from 2 to 85 days) \\
\hline \multirow{2}{*}{$\begin{array}{l}\text { Salazar et al., } \\
2017,(32)\end{array}$} & \multirow[t]{2}{*}{12,473} & \multirow{2}{*}{$\begin{array}{l}\text { Retrospective } \\
(2004 \rightarrow 2012)\end{array}$} & Length of stay $\leq 14$ days: 11,965 patients \\
\hline & & & Length of stay exceeding 14 days: 508 patients \\
\hline $\begin{array}{l}\text { Rodriguez et al., } \\
\text { 2012, (33) }\end{array}$ & 99 & $\begin{array}{l}\text { Retrospective } \\
(2006 \rightarrow 2010)\end{array}$ & $\begin{array}{l}\text { Median length of stay significantly prolonged for patients } \geq 70 \text { years old ( } 4 \text { vs. } 6 \text { days } \\
\text { for respectively patients }<70 \text { and } \geq 70 \text { years old); } P=0.03\end{array}$ \\
\hline $\begin{array}{l}\text { Lee et al., } \\
2011,(34)\end{array}$ & 148 & $\begin{array}{l}\text { Retrospective } \\
(2000 \rightarrow 2009)\end{array}$ & $\begin{array}{l}\text { Median stay in intensive care unit: } 0.74 \pm 0.57 \text { days in thoracoscopic lobectomy group } \\
\text { vs. } 0.97 \pm 0.37 \text { days in thoracotomy group }(P=0.004)\end{array}$ \\
\hline $\begin{array}{l}\text { Jiang et al., } \\
\text { 2011, (35) }\end{array}$ & 110 & $\begin{array}{l}\text { Retrospective } \\
(2004 \rightarrow 2010)\end{array}$ & $\begin{array}{l}\text { Median length of stay } 10.8 \pm 3.7 \text { days in VATS group vs. } 12.5 \pm 4.8 \text { days in thoracotomy } \\
\text { group }(P=0.043)\end{array}$ \\
\hline \multirow{2}{*}{$\begin{array}{l}\text { Bouchard et al., } \\
\text { 2008, (31) }\end{array}$} & \multirow{2}{*}{60} & \multirow{2}{*}{$\begin{array}{l}\text { Retrospective } \\
(2004 \rightarrow 2006)\end{array}$} & Median length of stay in hospital $9.3 \pm 5.4$ days \\
\hline & & & $\begin{array}{l}\text { Median length of stay was significantly shorter compared to patients who did not } \\
\text { receive } A C(P=0.0008)\end{array}$ \\
\hline
\end{tabular}

VATS, video-assisted thoracic surgery; AC, adjuvant chemotherapy.

comorbidities according to Charlson index and academic hospital (i.e., vs. community hospital) were associated with a less likelihood to receive AC $(14,28)$. Of note, histologic sub-type might be associated with a lower likelihood to receive $\mathrm{AC}$ as among a cohort of 94 patients who underwent curative-intent lung surgery for stage II-III squamous-cell carcinoma, only $25.5 \%$ of them received AC (29).

Prolonged length of stay in hospital after curative-intent lung surgery might contribute to a delayed administration of AC. The median length of stay in hospital was about 6 days in a retrospective study including 4,979 patients (30) while it was estimated at 8 (18) and 9.3 days (31) in two other retrospective cohorts of 219 and 60 patients respectively $(18,31)$ (Table 3). In a large retrospective study which enrolled 12473 patients who underwent AC after curative-intent lung resection, length of stay exceeded 14 days for 508 patients (32) (Table 3). Moreover, Bouchard et al. found that patients who underwent AC had significant shorter length of stay in hospital compared to those who did not receive $\mathrm{AC}(\mathrm{P}=0.0008)$ (31). In this setting, predictors for prolonged length of stay in hospital have been described. Wright et al. observed that patients with prolonged length of stay after lobectomy surgery have much more postoperative events $(3.4 v s .1 .2$ events, $\mathrm{P}<0.0001)$ associated with more comorbidities than the others (30). Similarly, postoperative complications were documented in $40 \%$ of patients, mainly postoperative infections (i.e., 35 patients among 87 patients who experienced postoperative complications) (18). Although no significant differences in postoperative complications, baseline comorbidities, surgical procedure and histologic sub-type, Rodriguez et al. identified age as a significant prognostic factor for prolonged length of stay after lung resection (33). Indeed, patients older than 70 years old had a significant prolonged length of stay in hospital and intensive care unit compared to younger patients (33) (Table 3). Finally, these retrospective studies highlighted that patients who underwent thoracotomy had prolonged length of stay in hospital compared to others (34,35) (Table 3).

Nowadays, according to guidelines, AC have to be 
initiated within 4 to 8 weeks after curative-intent lung surgery (10-12). The median time between surgery and AC was 40 days and 39 days in the IALT trial (2) and the LACE meta-analysis (5) respectively. For $7 \%$ of the patients, the delay to initiate AC exceeded 60 days in the IALT trial (2). In non-trial setting, several retrospective studies were interested in the median time from surgery to AC administration (32,34-43). In real-life practice, these retrospective studies showed that the delay of initiation of AC did not differ significantly compared to clinical trials (Table 4). Indeed, the median time between surgery and AC administration was approximately comprised between 5 to 8 weeks (32,34-43) (Table 4). Moreover, these studies showed that in real-life practice, AC administration might be delayed after 8 weeks following lung surgery (Table 4). In this context, predictors of delayed $\mathrm{AC}$ have been described (32,36-38). Squamous cell carcinoma, undetermined grade, pneumonectomy resection, extended length of stay in surgery and unplanned 30-day readmission have been identified as significant predictors of delayed initiation of AC $(32,36)$. Zhu et al. also identified higher rate of smoking history as a predictor of delayed AC administration (38). On the contrary, increased comorbidity according to Charlson index (36) and advanced age (39) were not associated with delayed AC. Finally, postoperative complications including infections (16\%), postoperative recovery of performance status $(32 \%)$, patient's decision $(18 \%)$ and referral delay to medical oncologist $(16 \%)$ were also described as main factors associated with a delayed AC (37). Interestingly, these retrospective studies outlined that delayed AC was not associated with an increased mortality risk $(32,36,38)$ (Table 4). Notably, patients who received delayed AC (i.e., after 57 days) had a lower mortality risk [HR (95\% CI): 0.664 (0.623-0.707); $\mathrm{P}<0.001]$ compared to patients treated with surgery alone (32). However, patients who received
AC $>8$ weeks after lung surgery have significant shorter OS compared to those who received AC within 8 weeks after lung resection (44). Finally, in accordance with hospital length stay after surgery, thoracotomy surgery is associated with a longer delay of AC administration compared to video-assisted thoracoscopic surgery (VATS) (42) (Table 4).

Overall, these retrospective studies highlighted that decision of AC administration is influenced by several predictors including patient's and physician's decision, patient's baseline characteristics, lung surgery and postoperative complications as well as referral to medical oncologist. Although no difference with main randomized clinical trials, all these predictive factors might also contribute with prolonged length of stay in hospital following surgery and thus, delayed AC administration. Otherwise, these retrospective studies outlined that although delayed; AC administration remains associated with a better prognosis compared to surgery alone.

\section{Is age a limiting factor to receive AC in real-life practice?}

Despite literature supporting AC use in completely resected IIA to IIIA NSCLC, there is actually a lack of literature data regarding AC use in elderly patients. Indeed, in main randomized clinical trials of AC in NSCLC, elderly patients did not meet the inclusion criteria. Of note, in IALT trial, there were only 4 patients older than 75 years old among 932 patients who received AC (2). In the ANITA trial, the median age in chemotherapy group was 59 years old, with no patients older than 75 years old included (4). Notably, sub-group analysis was conducted based on JBR.10. trial patients' cohort as the age varies from 35 to 82 years old in the chemotherapy group $(3,45)$. Pepe et al. analysed the population study of the JBR.10. trial by separating the population study into two groups

Table 4 Time from surgery to AC administration and impact on survival in real-life practice

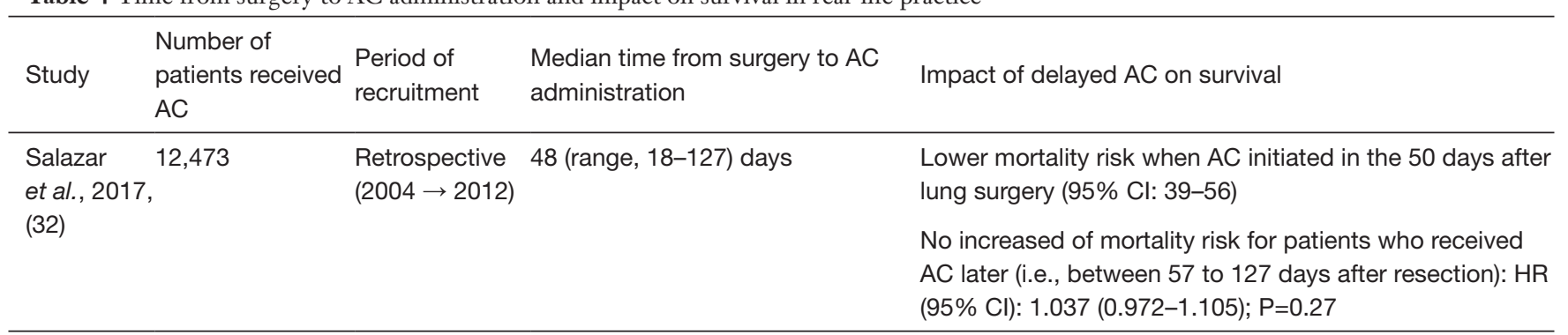

Table 4 (continued) 
Table 4 (continued)

\begin{tabular}{|c|c|c|c|c|}
\hline Study & $\begin{array}{l}\text { Number of } \\
\text { patients received } \\
\text { AC }\end{array}$ & $\begin{array}{l}\text { Period of } \\
\text { recruitment }\end{array}$ & $\begin{array}{l}\text { Median time from surgery to } A C \\
\text { administration }\end{array}$ & Impact of delayed AC on survival \\
\hline $\begin{array}{l}\text { Zhu et al., } \\
\text { 2016, (38) }\end{array}$ & 409 & $\begin{array}{l}\text { Retrospective } \\
(2003 \rightarrow 2013)\end{array}$ & $\begin{array}{l}81.9 \% \text { patients underwent } \\
\text { postoperative AC within } 46 \text { days: } \\
\text { median } 34 \text { (range, } 25-45 \text { ) days } \\
18.1 \% \text { patients underwent } \\
\text { postoperative AC in more than } \\
46 \text { days: median } 53.5 \text { (range, } \\
46-228 \text { ) days }\end{array}$ & $\begin{array}{l}\text { No significant difference in terms of DFS between patients } \\
\text { receiving AC either within } 46 \text { days after surgery \{median } \\
\text { DFS [ } 95 \% \text { Cl]: } 467 \text { [ } 450-552] \text { days\} or after } 46 \text { days from } \\
\text { surgery }\{\text { median DFS [95\% CI]: } 474 \text { [400-623] days\}; } \\
P=0.775\end{array}$ \\
\hline $\begin{array}{l}\text { Zhai et al., } \\
\text { 2016, (39) }\end{array}$ & 865 & $\begin{array}{l}\text { Retrospective } \\
(2001 \rightarrow 2013)\end{array}$ & $\begin{array}{l}62 \% \text { of patients received } A C \\
\text { between } 4 \text { to } 6 \text { weeks after surgery }\end{array}$ & - \\
\hline $\begin{array}{l}\text { Velcheti } \\
\text { et al., } 2007 \text {, } \\
\text { (40) }\end{array}$ & 40 & $\begin{array}{l}\text { Retrospective } \\
(2003 \rightarrow 2005)\end{array}$ & 49 (range, 16-188) days & - \\
\hline $\begin{array}{l}\text { Lee et al., } \\
2011,(34)\end{array}$ & 148 & $\begin{array}{l}\text { Retrospective } \\
(2000 \rightarrow 2009)\end{array}$ & $\begin{array}{l}28.1 \pm 10.7 \text { days in thoracotomy } \\
\text { group } \\
26.9 \pm 7.5 \text { days in thoracoscopic } \\
\text { lobectomy group }\end{array}$ & - \\
\hline $\begin{array}{l}\text { Teh et al., } \\
2014,(42)\end{array}$ & 44 & $\begin{array}{l}\text { Retrospective } \\
(2008 \rightarrow 2013)\end{array}$ & $\begin{array}{l}55.7 \pm 3.1 \text { days in VATS resection } \\
\text { group vs. } 68.2 \pm 4.3 \text { days in } \\
\text { thoracotomy group }(P=0.046)\end{array}$ & - \\
\hline $\begin{array}{l}\text { Shukuya } \\
\text { et al., 2009, } \\
\text { (43) }\end{array}$ & & $\begin{array}{l}\text { Retrospective } \\
(2005 \rightarrow 2008)\end{array}$ & $\begin{array}{l}\text { Median time from surgery to AC: } \\
41 \text { (range, 29-79) days }\end{array}$ & - \\
\hline \multirow[t]{4}{*}{$\begin{array}{l}\text { Wang et al., } \\
2016,(44)\end{array}$} & 1,522 & $\begin{array}{l}\text { Retrospective } \\
(2004 \rightarrow 2010)\end{array}$ & $\begin{array}{l}10 \% \text { patients received } \mathrm{AC} \\
<30 \text { days after surgery }\end{array}$ & \multirow{4}{*}{$\begin{array}{l}\text { Patients who received } A C>60 \text { days after surgery have a } \\
\text { shorter OS compared to other patients who received } A C \\
<60 \text { days after surgery }(P=0.0034)\end{array}$} \\
\hline & & & $\begin{array}{l}17.1 \% \text { received } A C \text { between } \\
0-45 \text { days after surgery }\end{array}$ & \\
\hline & & & $\begin{array}{l}19.05 \% \text { received } A C \text { between } \\
45-60 \text { days after surgery }\end{array}$ & \\
\hline & & & $\begin{array}{l}53.7 \% \text { received } A C>60 \text { days after } \\
\text { surgery }\end{array}$ & \\
\hline
\end{tabular}

AC, adjuvant chemotherapy; OS, overall survival; DFS, disease-free survival; VATS, video-assisted thoracic surgery. 
according to the age (i.e., patients younger or older than 65 years old) (45). Although a potential bias of well selected aged patients, this sub-group analysis outlined that AC can be used safely in elderly patients. Indeed, no significant differences were reported between age groups in terms of chemotherapy toxicities, rate of hospitalization and treatment-related death (45). Moreover, this sub-group analysis highlighted that unless elderly patients received lower intensities of cisplatin-vinorelbine, AC use remained a significant prognostic factor of prolonged OS for patients older than 65 years old [adjusted HR (95\% CI): 0.61 (0.380.98); $\mathrm{P}=0.04$ ] compared to surgery alone (45). Likewise, the sub-group analysis of the LACE meta-analysis according to the age (i.e., $<65,65-70$, and $>70$ years old) revealed no significant differences of AC related toxicities (46). As well, the oldest patients received lower doses of cisplatin and lower number of AC cycles. Indeed, only $42 \%$ of the elderly patients received a total cisplatin dose $\geq 275 \mathrm{mg} / \mathrm{m}^{2}$ in comparison with $64 \%$ of young patients $(\mathrm{P}<0.0001)$ and; $58 \%$ of the elderly patients received more than two or three of the four planned chemotherapy cycles, compared with $77 \%$ of young patients (46).

In non-trial setting, several retrospective studies outlined that older patients received significantly less AC compared to their younger counterparts. Indeed, AC use for patients older than 70 years old ranged from $10 \%$ to $25 \%(33,47-51)$ (Table 5). This might be related to a less referral to medical oncologist (52). Otherwise, older patients have a higher likelihood to receive AC in case of higher stage disease, as $42 \%$ of patients older than 70 years old with stage IIIA disease were treated with AC (51). Moreover, most of these retrospective studies highlighted that there was no significant difference in chemotherapy regimen received $(39,48,54,55)$ (Table 5). Among these, only two studies reported that elderly patients received more frequently Carboplatin-based $(\mathrm{P}<0.0001)$ (49) or Carboplatin-paclitaxel regimen compared to younger (without a statistical significance) (55) (Table 5).

In real-life practice, despite contradictory data (33), no significant differences in the number of chemotherapy cycles received was observed between younger and older patients $(39,54)$. Of note, the percentage of patients older than 65 years old who completed four cycles of AC ranged from $61 \%(50)$ to $92.4 \%(39,54,55)$ (Table 5). Likewise, no significant differences in terms of dose intensity received was reported (55). A dose reduction was reported among $30 \%$ (48) to $40.9 \%$ (55) of older patients while a dose omission was observed between $21 \%$ to $32 \%$ of cases (48)
(Table 5). As an assessment of well-tolerated AC in this specific population, no significant difference was reported between patients younger and older than 65 years old regarding hematologic toxicities, except for all grade anemia (55). Notably, grade 3-4 neutropenia was not significantly more frequent in older patients (i.e., 39.4\%) compared to their younger counterparts (i.e., 41.1\%) (55). Adverse events reported by elderly patients during AC treatment were sore mouth $(\mathrm{P}=0.0032)$, peripheral neuropathy $(\mathrm{P}<0.001)$ and alopecia $(\mathrm{P}<0.001)(55)$. Overall, quality of life (QOL) during AC treatment did not significantly deteriorate among elderly patients (55).

More interestingly, several studies outlined that AC is efficient in this sub-population (39,49-51,53-55) (Table 5). Indeed, AC significantly improved OS compared to surgery alone among patients older than 66 (49) or 70 years old $(51,53)$. As well, no significant differences were reported between younger and older patients who received AC in terms of OS (49-51,53-55) and DFS (39,54,55) (Table 5). However, Wisnivesky et al. observed that AC use was not associated with a survival benefit for patients older than 80 years old (53).

Overall, these retrospective studies showed that unless $\mathrm{AC}$ is used less frequently among elderly patients, AC remains safe and efficient in non-trial setting. As for their younger counterparts, fit older patients should be treated with platinum based chemotherapy; cisplatin remained preferrable if patient suitable to receive it (56). As an exception, AC use might be carefully discussed for patients older than 80 years old as no survival benefit was observed $(53,57)$. Otherwise, chronological age should not be considered as a limiting factor to receive $\mathrm{AC}$ as well as performance status (57). Indeed, several reviews on AC use in clinical practice among elderly patients, outlined that comprehensive geriatric assessment is of particular interest to limit both over and undertreatment in this specific population (56-61).

\section{Which type of chemotherapy is used in real-life practice? Are patients received the planned dose of AC?}

$\mathrm{AC}$, and in particular cisplatin-based regimen, may have toxicity. Consequently, this arises the question of patients who subsequently received $\mathrm{AC}$ when recommended as well as the regimen and dose intensity received in non-trial setting.

According to main randomized clinical trials, among patients assigned to receive $\mathrm{AC}$, the percentage of patients 


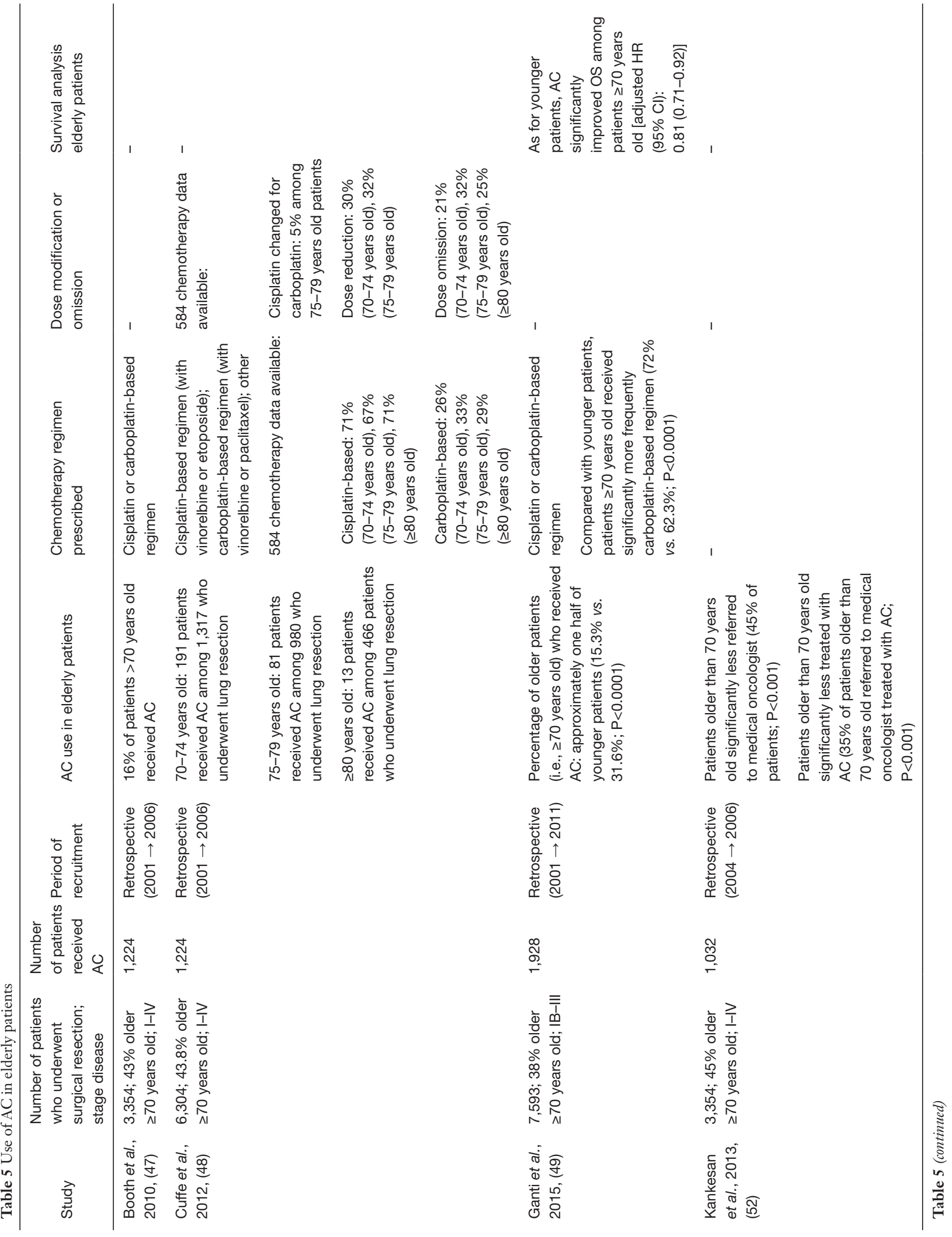




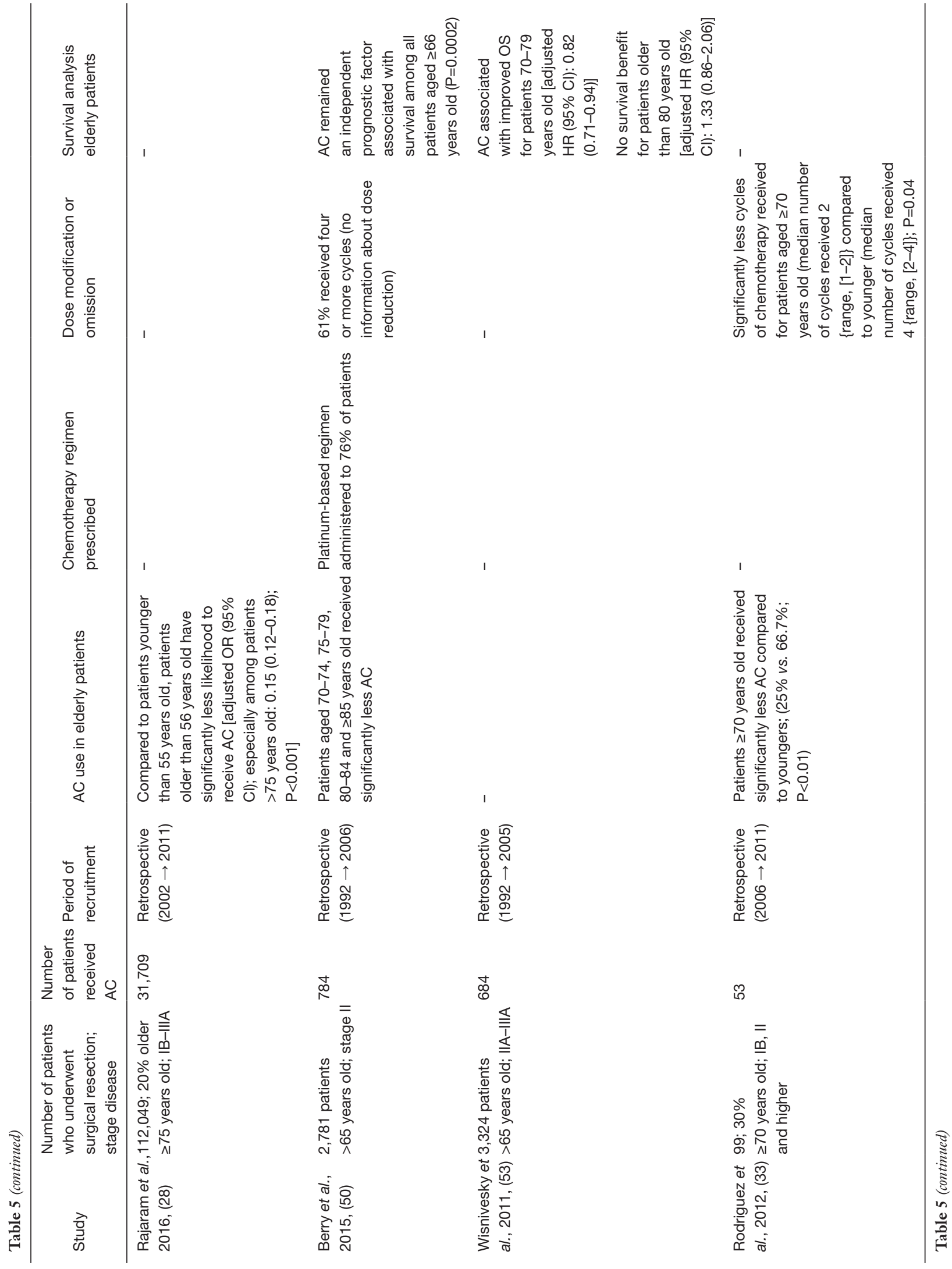




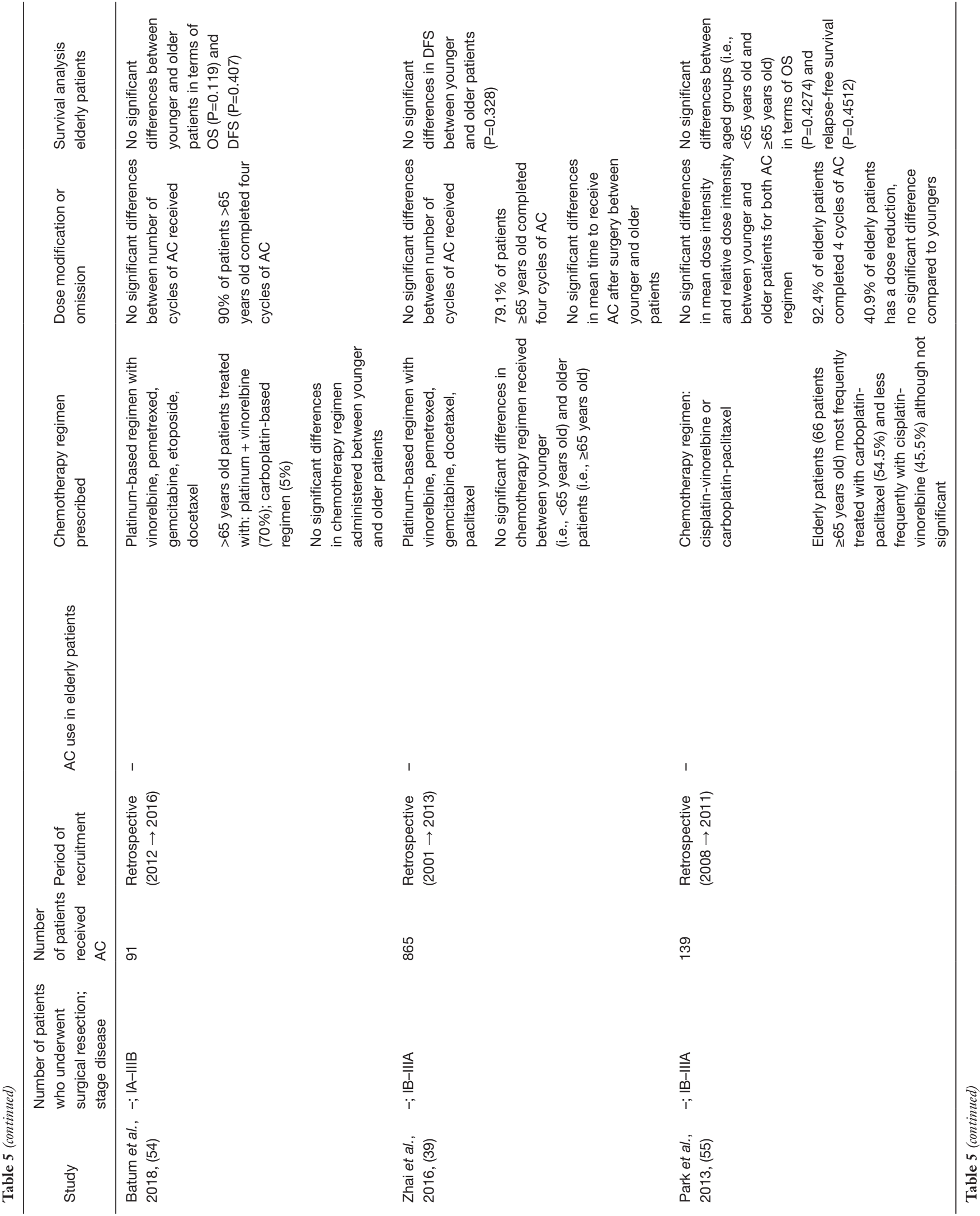




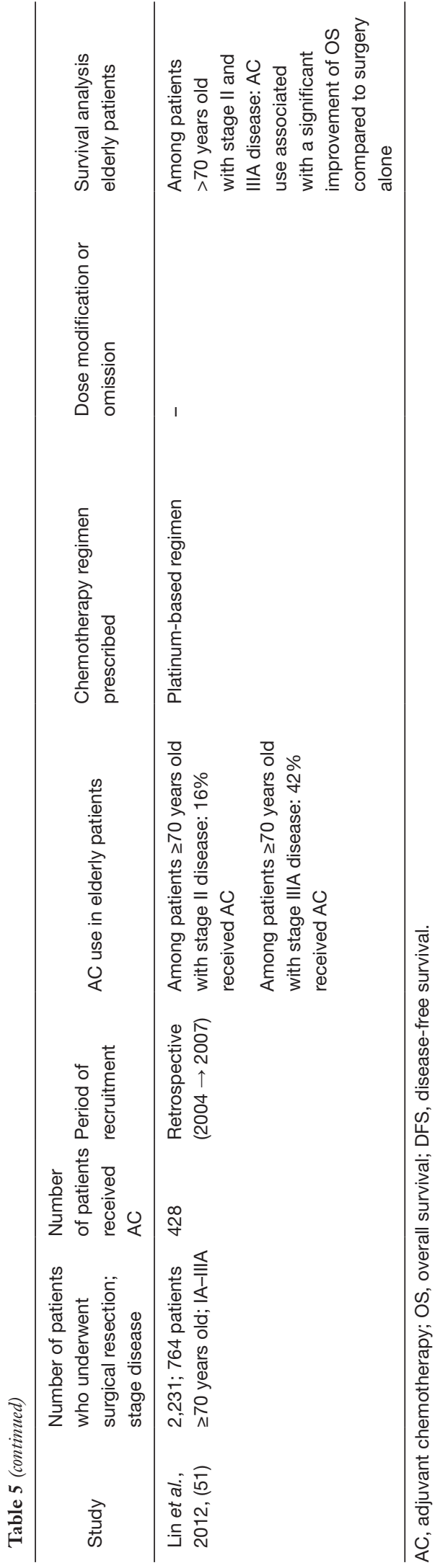

who never received chemotherapy ranged from $4.5 \%$ to $9.8 \%$ (2-4); mainly due to patient's refusal. Among patients who received AC, $73.8 \%$ received at least $240 \mathrm{mg} / \mathrm{m}^{2}$ of cisplatin in the IALT trial (2) while $38 \%$ and $63 \%$ patients received more than $66 \%$ of the total planned dose of vinorelbine and cisplatin respectively in ANITA trial (4) (Table 1). In the LACE meta-analysis, $59 \%$ of patients received at least $240 \mathrm{mg} / \mathrm{m}^{2}$ of cisplatin (5) (Table 1). The median number of cycles delivered was three in the JBR.10. trial (3); 77\% of patients had at least one dose reduction or omission and $55 \%$ required at least one dose delay (3). Main factors associated with incomplete chemotherapy planned in IALT trial were adverse events $(51.5 \%)$, patient's or physician's decision $(24.3 \%)$ and disease progression $(5.1 \%)$ or early death (8.1\%) (2). Similarly to the IALT trial, the main reasons for receiving less than the planned number of AC cycles were patient's refusal (35\%), toxicity (34\%) and early death or progression (9\%) in the LACE meta-analysis (5).

Firstly, these studies highlight that cisplatin-based regimen is the most frequently used in non-trial setting (Table 6). Of note, consistently with guidelines, cisplatinvinorelbine is the most frequently AC regimen prescribed by physicians in real-life practice (Table 6). On the contrary, only two retrospective studies mentioned that carboplatinpaclitaxel regimen was the most frequently prescribed AC regimen $(24,66)$. Otherwise, these studies either included patients previously main randomized clinical trials were published (66) or recently published (24) and; the median age of patients was older than 66 years old (66). In this setting, initial chemotherapy regimen was changed for $6 \%(62)$ to $8 \%$ (63) of patients (i.e., mainly cisplatin for carboplatin-based regimen). The main reasons involved for this chemotherapeutic change were nephrotoxicity, asthenia and vomiting (63). Although heterogeneity data $(18,22,41,68,70)$, the number of patients who completed four cycles of AC ranged from $71 \%$ to $92 \%$ in non-trial setting (Table 6). In particular, the percentage of patients who received the total planned dose ranged from $40 \%$ (40) to $78.4 \%$ (34). Moreover, patients experience dose reduction or omission in a range of $40 \%$ (63) to $64 \%$ (62) (Table 6). In particular, dose reduction was significantly associated with cisplatin-used $(\mathrm{P}=0.004)$ and poorer ECOG (i.e., performance status $0-1$ as reference, $\mathrm{P}=0.020$ ) (37). In line with these observations, cisplatin-vinorelbine regimen was significantly associated with higher frequency of dose delay or dose reduction compared to patients treated with carboplatin-paclitaxel (70). Although dose modification was not found to be associated with inferior survival (62), 


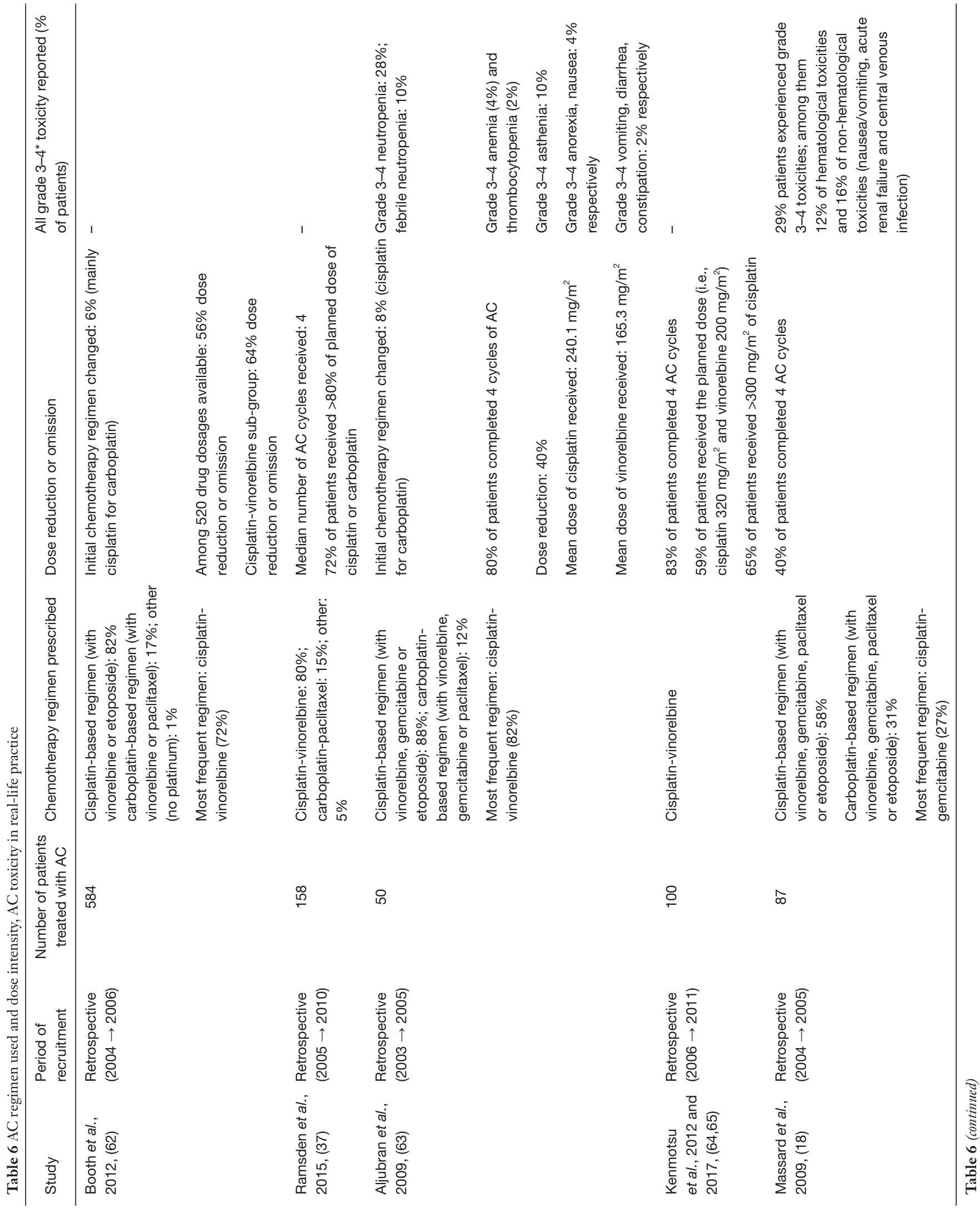




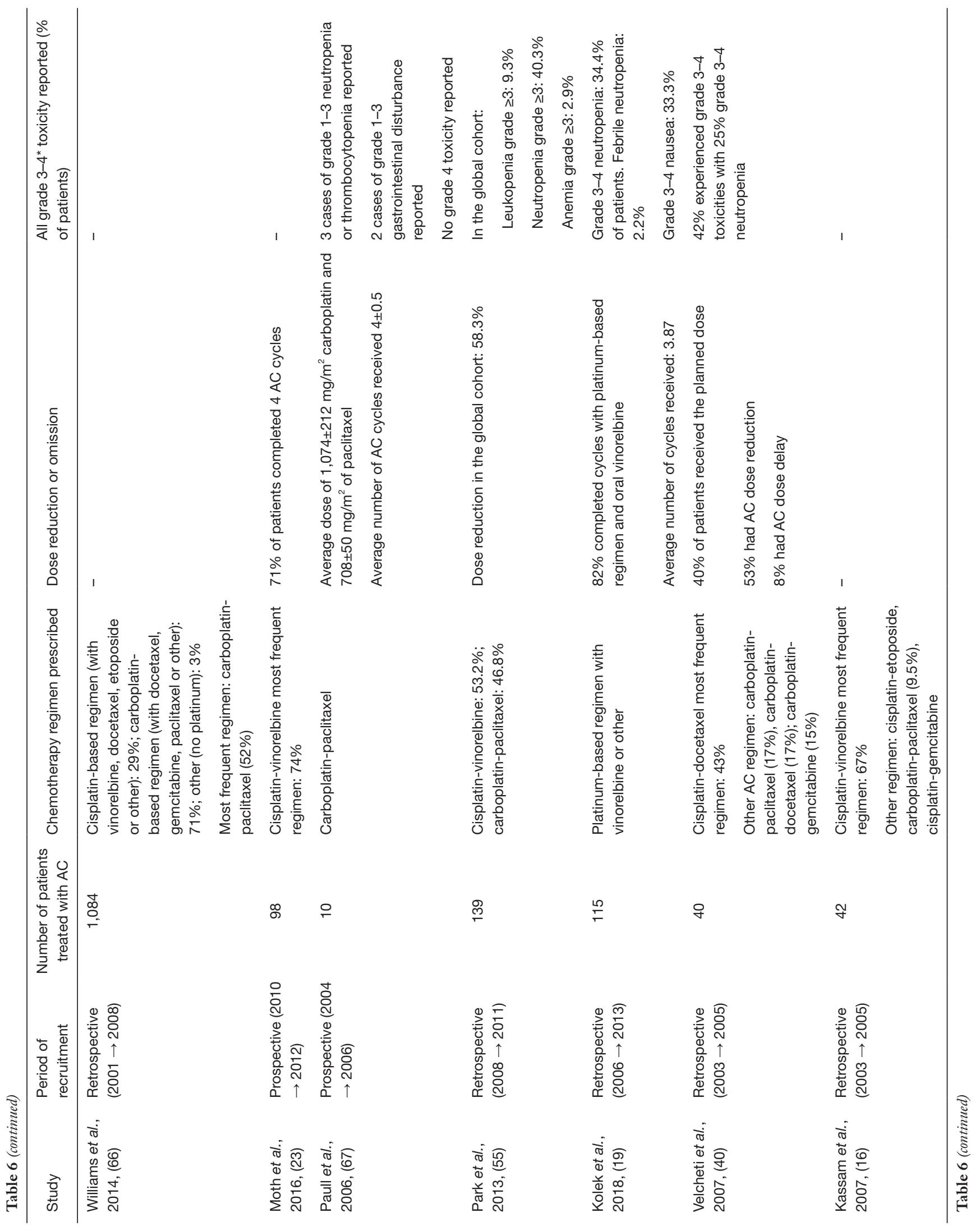




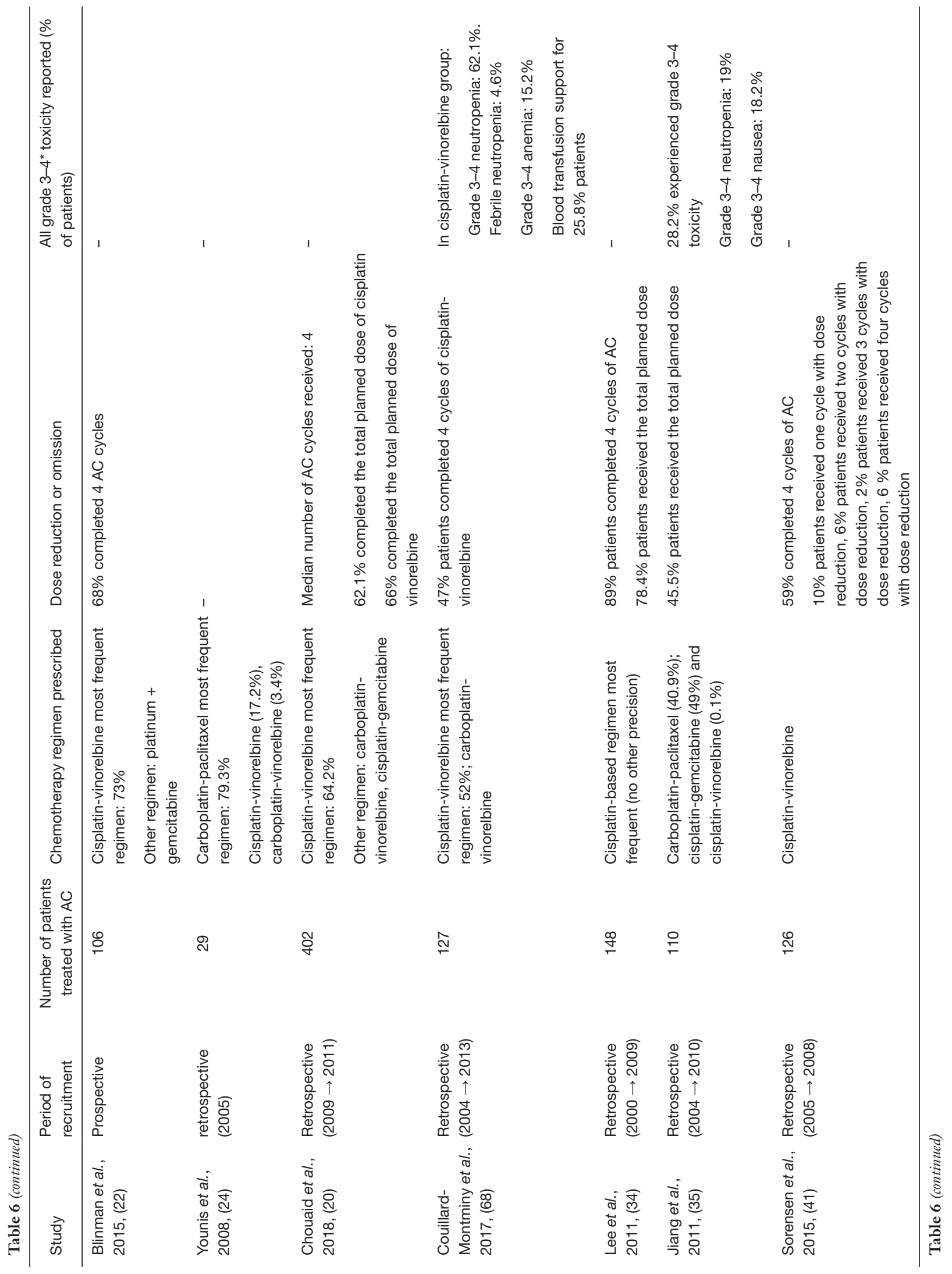




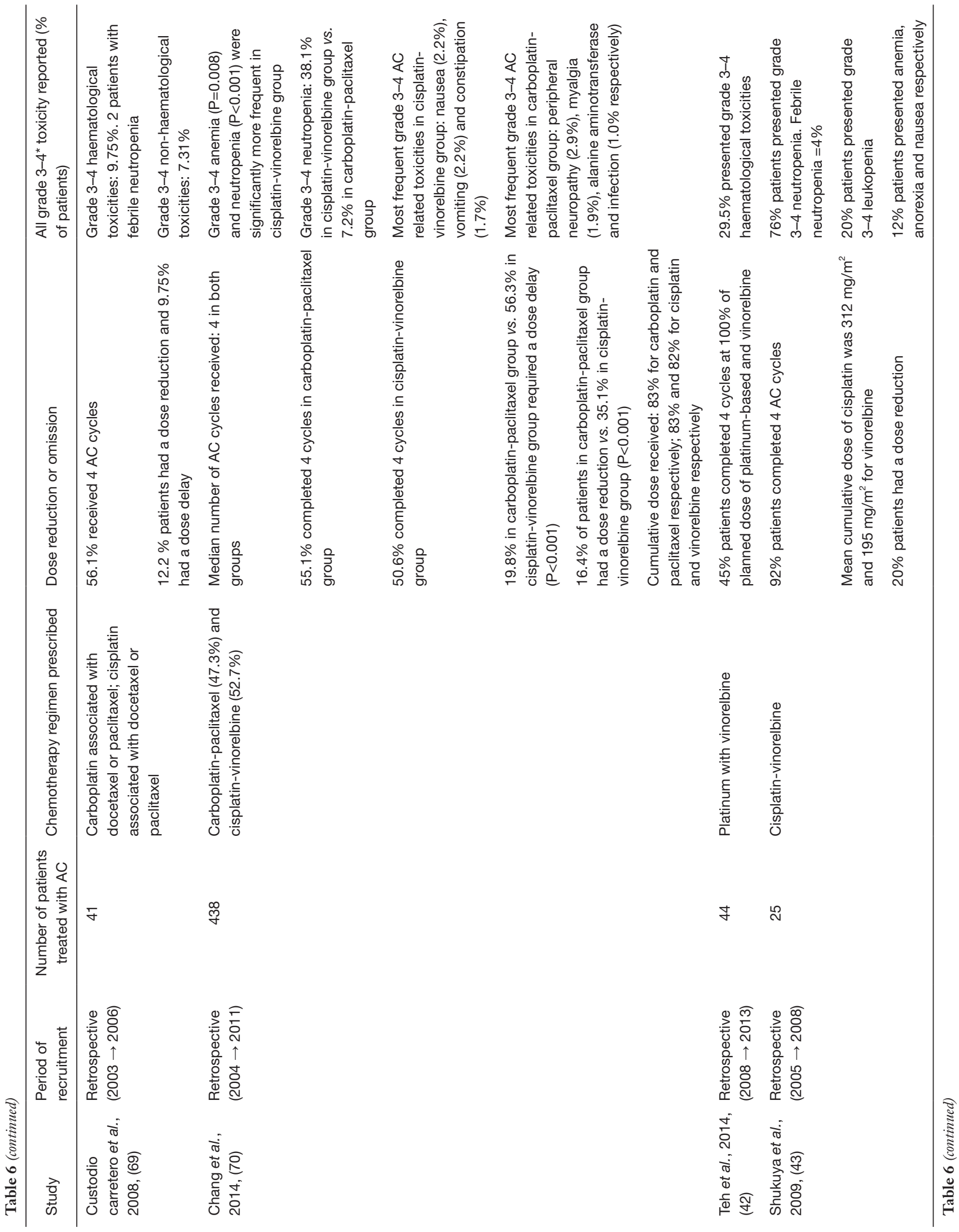


Ramsden et al. showed that patients with a delivery of $<80 \%$ of total planned platinum dose was a significant factor affecting OS (37). Likewise, the number of AC cycles received is important to consider as patients who received four AC cycles had a significant prolonged DFS compared to those who received less than four cycles of AC [HR (95\% CI): 0.727 (0.552-0.958); $\mathrm{P}=0.0023]$ (39). On the contrary, Kenmotsu et al. found that the total dose of cisplatin received was not a prognostic factor (64). Finally, main reasons for discontinuation of $\mathrm{AC}$ were $\mathrm{AC}$ toxicities (i.e., $8 \%$ ) and patient's refusal (i.e., $8 \%$ ) $(64,65)$. Finally, thoracoscopy seems to be associated with higher compliance to AC compared to thoracotomy $(34,35)$. Indeed, a significant higher rate of patients completed $4 \mathrm{AC}$ cycles in case of thoracoscopy compared to thoracotomy $(34,35)$.

Taken together, these studies showed that physicians prescribe mostly cisplatin-vinorelbine regimen. In a population of less-selected patients, literature data showed that the percentage of patients who received either $4 \mathrm{AC}$ cycles or experienced dose reduction or omission is not different compared to randomized clinical trials.

\section{AC related toxicities}

Finally, a major point to take into account in real-life practice is the toxicity of $\mathrm{AC}$, which can lead to either dose reduction or omission and incomplete planned dose received. In main randomized clinical trials, the rate of overall grade 3-4 toxicity was estimated at $66 \%$ (5). In particular, neutropenia was reported as the most frequent serious adverse event occurring in patients treated with AC: $9 \%$ grade 3 and $28 \%$ grade 4 neutropenia reported in the LACE meta-analysis while $73 \%$ and $76 \%$ of patients experienced grade 3 or 4 neutropenia in the JBR.10. and ANITA trials respectively (Table 1).

Similar to AC clinical trials, neutropenia remains the most frequent adverse event reported in real-life practice (Table 6). In contrast with Shukuya et al. (43) who reported $76 \%$ of patients experienced grade 3-4 neutropenia, other studies highlight that in non-trial setting neutropenia occurrence is not more frequent compared with randomized clinical trials (Table 6). Indeed, the rate of grade 3-4 neutropenia ranged from $19 \%$ (35) to $62.1 \%$ (68), with up to $10 \%$ of patients who experienced febrile neutropenia (63) (Table 6). In this setting, neutropenia was significantly more frequent in case of cisplatin-vinorelbine regimen $(\mathrm{P}<0.001)(70)$. In real-life practice, other AC adverse events frequently reported were asthenia, anorexia and nausea- 
vomiting (Table 6). Moreover, AC related toxic death was low in randomized clinical trials with a rate ranging from $0.8 \%$ to $2 \%$ (Table 1). Similar observations were reported according to retrospective studies in real-life practice $(18,40,62,64,65,69)$. Indeed, $0.009 \%$ to $1.6 \%$ related AC toxicity death were reported by Massard et al. (18) and Booth et al. (62) respectively, while other retrospective studies reported no AC toxic death $(40,64,65,69)$. In this context, predictors of early mortality (i.e., within 6 months following AC administration) have been identified (71). Prolonged length of stay in hospital ( $>6$ days), 30-day readmission on hospital, higher stage disease, higher comorbidities according to Charlson index (i.e., $\geq 2$ ) and pneumonectomy were significantly associated with higher risk of early mortality following $\mathrm{AC}$ administration (71). Notably, AC related toxic death seems to be more frequent in older patients. Indeed, AC related toxic death within 12 weeks following AC administration was estimated at $3.1 \%$ among a population of 684 patients with a mean age of 71.5 years old (53). Moreover, this retrospective study outlined the increased risk of dehydration in this specific population which occurred in $6.7 \%$ (53). In accordance with Wisnivesky et al., patients older than 80 years old or aged between 70 and 80 years old were also identified at higher risk of early mortality (i.e., within 6 months following $\mathrm{AC}$ administration) compared with younger patients (i.e., $<50$ years old) (71). The mortality rate at 6 months was $7.6 \%$ among patients older than 80 years old (71).

Finally, sub-group analysis of the JBR.10. trial showed that patients had transient worsening QOL scores following AC (72). Otherwise, these scores were found to return to baseline within 9 months following AC, except for sensory neuropathy (72). In non-trial setting, patients also experienced a transient worsening QOL partially associated with AC administration (67). Indeed, Paull et al. reported all three measures of global QOL (Trial Outcome Index, Functional Assessment of Cancer Therapy-Lung and Functional Assessment of Cancer Therapy-General) as well as the subscales of physical and functional well-being at baseline and after lung resection among 37 patients for a stage I-III NSCLC disease. These scores were significantly decreased at 0 to 3 months compared with baseline whereas these scores were not significantly different from baseline after 3 months (67).

Overall, consistently with clinical trials, literature data regarding AC toxicity in non-trial setting highlight that $\mathrm{AC}$ use is mostly associated with a risk of neutropenia. AC administration remains well-tolerated in most of patients and might be associated with a transient worsening QOL.

\section{Discussion}

At the beginning of 2000, AC has been implemented in NSCLC with the aim to reduce the risk of disease recurrence through eliminating residual disease. To our knowledge, this is the first systematic literature review reporting AC use for resected NSCLC patients in real-life practice as previous reviews on this topic focused on $\mathrm{AC}$ use in elderly patients. This systematic literature review highlights a lack of literature data regarding AC use in reallife practice, as most of these were retrospective studies. Although data from large registries such as National Cancer Database or SEER (Surveillance, Epidemiology and End Results program) database, most of the retrospective studies included were either monocentric or multicentric with a limited number of patients which might limit external validity of results. Similarly, retrospective studies are also subjected to potential bias, in particular selection bias and information or misclassification bias. As well, although broad search terms were applied in the request formulated on several research database in order not to miss relevant articles, only one author carried out the selection and peer-reviewed process which constitute a potential bias of selection. Otherwise, the eligibility and the relevance of articles selected was peer-reviewed by all authors.

Despite the absence of a control group and the quality of data sources and collection, RWE has gained increased interest recently as they could focus on a specific population underrepresented in randomized clinical trials or provide pharmaco-economic data. There is a lack of RWE regarding AC use in resected NSCLC patients. In this setting, RWE would be interesting to evaluate AC use in elderly patients or in stage IB disease as AC use remains controversial in these specific populations. Notably, in the context of adjuvant immunotherapy and targeted therapies development, RWE on AC would be valuable to define which patients would better benefit from these different therapeutic options in next future and provide pharmacoeconomic data.

Consistently with randomized clinical trials, this systematic literature review shows that benefit outweigh the risk is in favour of AC use when recommended. Indeed, in a less-selected population, AC use remains safe and associated with a therapeutic efficacy. In particular, this systematic review highlights that $\mathrm{AC}$ could be used in fit elderly patients-especially for those younger than 80 years old- 
which is a frequent clinical situation in daily-life practice. Furthermore, delayed AC remains efficient compared to surgery alone.

Nowadays, guidelines for AC administration are mainly based on patient's clinical characteristics (age, performance status) and NSCLC disease's characteristics. In this context, there has been a great interest to identify prognostic and predictive biomarkers of AC treatment to better select patients. However, these interesting markers such as DNA methylation, miRNA or gene signatures have not proven their clinical value in prospective trials yet (73). In this context, other biomarkers currently used in metastatic context tend to be used as well in early-stage NSCLC disease. Thus, the specific place of standard AC has to be precised in the next future since targeted therapies and immunotherapy seem promising strategies in adjuvant setting. Indeed, although the therapeutic efficacy of PD-1 and PD-L1 antibodies remain currently unclear in adjuvant treatment strategies for NSCLC, preliminary results of phase III IMpower010 (NCT02486718) randomized clinical trial hopes for future. Primary results recently reported at ASCO (American Society of Clinical Oncology) meeting 2021 showed that patients who received atezolizumab following AC have significant increased DFS compared to best supportive care $(\mathrm{P}=0.0395$ after a median followup of 32.2 months) (74). In the same way, other phase III randomized trials are currently ongoing to evaluate the impact of immune checkpoint inhibitors on DFS following AC treatment (ANVIL trial NCT02595944; PEARLS/ Keynote091 trial NCT02504372; BR31 Canadian Cancer Trial Group NCT02273375). In case of oncogenic-driven mutations, ADAURA trial recently demonstrated that osimertinib significantly prolonged DFS after curativeintent lung surgery compared to placebo for patients harbouring $E G F R$-sensitizing mutations (i.e., del19 and L858R EGFR mutations), regardless patients received AC or not (75).

To conclude, despite a lack of literature regarding AC use in real-life practice, this systematic literature review reports that AC use is safe and efficient in non-trial setting. Several strategies are currently under development to better select patients that will benefit from AC and to implement other strategies depending on immune checkpoint inhibitors and targeted therapies.

\section{Acknowledgments}

Funding: None.

\section{Footnote}

Reporting Checklist: The authors have completed the PRISMA reporting checklist. Available at https://dx.doi. org/10.21037/tlcr-21-557

Conflicts of Interest: All authors have completed the ICMJE uniform disclosure form (available at https://dx.doi. org/10.21037/tlcr-21-557). The authors have no conflicts of interest to declare.

Ethical Statement: The authors are accountable for all aspects of the work in ensuring that questions related to the accuracy or integrity of any part of the work are appropriately investigated and resolved.

Open Access Statement: This is an Open Access article distributed in accordance with the Creative Commons Attribution-NonCommercial-NoDerivs 4.0 International License (CC BY-NC-ND 4.0), which permits the noncommercial replication and distribution of the article with the strict proviso that no changes or edits are made and the original work is properly cited (including links to both the formal publication through the relevant DOI and the license). See: https://creativecommons.org/licenses/by-nc-nd/4.0/.

\section{References}

1. Bray F, Ferlay J, Soerjomataram I, et al. Global cancer statistics 2018: GLOBOCAN estimates of incidence and mortality worldwide for 36 cancers in 185 countries. CA Cancer J Clin 2018;68:394-424.

2. Arriagada R, Bergman B, Dunant A, et al. Cisplatinbased adjuvant chemotherapy in patients with completely resected non-small-cell lung cancer. $\mathrm{N}$ Engl J Med 2004;350:351-60.

3. Winton T, Livingston R, Johnson D, et al. Vinorelbine plus cisplatin vs. observation in resected non-small-cell lung cancer. N Engl J Med 2005;352:2589-97.

4. Douillard JY, Rosell R, De Lena M, et al. Adjuvant vinorelbine plus cisplatin versus observation in patients with completely resected stage IB-IIIA non-small-cell lung cancer (Adjuvant Navelbine International Trialist Association [ANITA]): a randomised controlled trial. Lancet Oncol 2006;7:719-27. Erratum in: Lancet Oncol 2006;7:797.

5. Pignon JP, Tribodet H, Scagliotti GV, et al. Lung adjuvant cisplatin evaluation: a pooled analysis by the LACE Collaborative Group. J Clin Oncol 2008;26:3552-9. 
6. Burdett S, Pignon JP, Tierney J, et al. Adjuvant chemotherapy for resected early-stage non-small cell lung cancer. Cochrane Database Syst Rev 2015;(3):CD011430.

7. Scagliotti GV, Fossati R, Torri V, et al. Randomized study of adjuvant chemotherapy for completely resected stage I, II, or IIIA non-small-cell Lung cancer. J Natl Cancer Inst 2003;95:1453-61.

8. Waller D, Peake MD, Stephens RJ, et al. Chemotherapy for patients with non-small cell lung cancer: the surgical setting of the Big Lung Trial. Eur J Cardiothorac Surg 2004;26:173-82.

9. Strauss GM, Herndon JE 2nd, Maddaus MA, et al. Adjuvant paclitaxel plus carboplatin compared with observation in stage IB non-small-cell lung cancer: CALGB 9633 with the Cancer and Leukemia Group B, Radiation Therapy Oncology Group, and North Central Cancer Treatment Group Study Groups. J Clin Oncol 2008;26:5043-51.

10. Eberhardt WE, De Ruysscher D, Weder W, et al. 2nd ESMO Consensus Conference in Lung Cancer: locally advanced stage III non-small-cell lung cancer. Ann Oncol 2015;26:1573-88

11. Vansteenkiste J, Crinò L, Dooms C, et al. 2nd ESMO Consensus Conference on Lung Cancer: early-stage nonsmall-cell lung cancer consensus on diagnosis, treatment and follow-up. Ann Oncol 2014;25:1462-74.

12. Kris MG, Gaspar LE, Chaft JE, et al. Adjuvant Systemic Therapy and Adjuvant Radiation Therapy for Stage I to IIIA Completely Resected Non-Small-Cell Lung Cancers: American Society of Clinical Oncology/Cancer Care Ontario Clinical Practice Guideline Update. J Clin Oncol 2017;35:2960-74.

13. Barni S, Maiello E, Di Maio M, et al. Adherence to AIOM (Italian Association of Medical Oncology) lung cancer guidelines in Italian clinical practice: Results from the RIGHT-3 (research for the identification of the most effective and highly accepted clinical guidelines for cancer treatment) study. Lung Cancer 2015;90:234-42.

14. Toubat O, Atay SM, Kim AW, et al. Disparities in Guideline-Concordant Treatment for Pathologic N1 Non-Small Cell Lung Cancer. Ann Thorac Surg 2020;109:1512-20.

15. Winget M, Stanger J, Gao Z, et al. Predictors of surgery and consult with an oncologist for adjuvant chemotherapy in early stage NSCLC patients in Alberta, Canada. J Thorac Oncol 2009;4:629-34.

16. Kassam F, Shepherd FA, Johnston M, et al. Referral patterns for adjuvant chemotherapy in patients with completely resected non-small cell lung cancer. J Thorac
Oncol 2007;2:39-43.

17. Nelson DB, Mehran RJ, Mitchell KG, et al. Enhanced recovery after thoracic surgery is associated with improved adjuvant chemotherapy completion for non-small cell lung cancer. J Thorac Cardiovasc Surg 2019;158:279-286.e1.

18. Massard C, Tran Ba Loc P, Haddad V, et al. Use of adjuvant chemotherapy in non-small cell lung cancer in routine practice. J Thorac Oncol 2009;4:1504-10.

19. Kolek V, Losse S, Kultan J, et al. Real life adjuvant chemotherapy uptake and survival in patients with nonsmall cell lung cancer after complete resection. Curr Med Res Opin 2018;34:1687-94.

20. Chouaid C, Danson S, Andreas S, et al. Adjuvant treatment patterns and outcomes in patients with stage IB-IIIA nonsmall cell lung cancer in France, Germany, and the United Kingdom based on the LuCaBIS burden of illness study. Lung Cancer 2018;124:310-6.

21. Ahmad U, Crabtree TD, Patel AP, et al. Adjuvant Chemotherapy Is Associated With Improved Survival in Locally Invasive Node Negative Non-Small Cell Lung Cancer. Ann Thorac Surg 2017;104:303-7.

22. Blinman P, Hughes B, Crombie C, et al. Patients' and doctors' preferences for adjuvant chemotherapy in resected non-small-cell lung cancer: What makes it worthwhile? Eur J Cancer 2015;51:1529-37.

23. Moth E, McLachlan SA, Veillard AS, et al. Patients' preferred and perceived roles in making decisions about adjuvant chemotherapy for non-small-cell lung cancer. Lung Cancer 2016;95:8-14.

24. Younis T, Al-Fayea T, Virik K, et al. Adjuvant chemotherapy uptake in non-small cell lung cancer. J Thorac Oncol 2008;3:1272-8.

25. Saint-Jacques N, Rayson D, Al-Fayea T, et al. Waiting times in early-stage non-small cell lung cancer (NSCLC). J Thorac Oncol 2008;3:865-70.

26. Pai RK, Rathinam S, Sharma V, et al. Postoperative oncological referral patterns for adjuvant treatment of patients undergoing curative resections for non-smallcell lung cancer at a regional thoracic centre. Eur J Cardiothorac Surg 2010;37:782-6.

27. Shukuya T, Takahashi T, Tamiya A, et al. Actual status of adjuvant chemotherapy for non-small-cell lung cancer at one Japanese cancer center: the need for increased cooperation between medical oncologists and surgeons. Med Oncol 2010;27:932-7.

28. Rajaram R, Paruch JL, Mohanty S, et al. Patterns and Predictors of Chemotherapy Use for Resected Non-Small Cell Lung Cancer. Ann Thorac Surg 2016;101:533-40. 
29. Isaka T, Nakayama H, Yokose T, et al. Platinum-Based Adjuvant Chemotherapy for Stage II and Stage III Squamous Cell Carcinoma of the Lung. Ann Thorac Cardiovasc Surg 2017;23:19-25.

30. Wright CD, Gaissert HA, Grab JD, et al. Predictors of prolonged length of stay after lobectomy for lung cancer: a Society of Thoracic Surgeons General Thoracic Surgery Database risk-adjustment model. Ann Thorac Surg 2008;85:1857-65; discussion 1865.

31. Bouchard N, Laberge F, Raby B, et al. Adjuvant chemotherapy in resected lung cancer: two-year experience in a university hospital. Can Respir J 2008;15:270-4.

32. Salazar MC, Rosen JE, Wang Z, et al. Association of Delayed Adjuvant Chemotherapy With Survival After Lung Cancer Surgery. JAMA Oncol 2017;3:610-9.

33. Rodriguez KA, Guitron J, Hanseman DJ, et al. Adjuvant chemotherapy and age-related biases in non-small cell lung cancer. Ann Thorac Surg 2012;94:1810-4.

34. Lee JG, Cho BC, Bae MK, et al. Thoracoscopic lobectomy is associated with superior compliance with adjuvant chemotherapy in lung cancer. Ann Thorac Surg 2011;91:344-8.

35. Jiang G, Yang F, Li X, et al. Video-assisted thoracoscopic surgery is more favorable than thoracotomy for administration of adjuvant chemotherapy after lobectomy for non-small cell lung cancer. World J Surg Oncol 2011;9:170.

36. Booth CM, Shepherd FA, Peng Y, et al. Time to adjuvant chemotherapy and survival in non-small cell lung cancer: a population-based study. Cancer 2013;119:1243-50.

37. Ramsden K, Laskin J, Ho C. Adjuvant Chemotherapy in Resected Stage II Non-small Cell Lung Cancer: Evaluating the Impact of Dose Intensity and Time to Treatment. Clin Oncol (R Coll Radiol) 2015;27:394-400.

38. Zhu Y, Zhai X, Chen S, et al. Exploration of optimal time for initiating adjuvant chemotherapy after surgical resection: A retrospective study in Chinese patients with stage IIIA non-small cell lung cancer in a single center. Thorac Cancer 2016;7:399-405.

39. Zhai X, Yang L, Chen S, et al. Impact of age on adjuvant chemotherapy after radical resection in patients with nonsmall cell lung cancer. Cancer Med 2016;5:2286-93.

40. Velcheti V, Viswanathan AK, Baggstrom MQ, et al. Drug delivery and toxicity of adjuvant chemotherapy for nonsmall cell lung cancer (NSCLC): Washington University experience. Acta Oncol 2007;46:869-70.

41. Sorensen SF, Carus A, Meldgaard P. Intravenous or oral administration of vinorelbine in adjuvant chemotherapy with cisplatin and vinorelbine for resected NSCLC. Lung
Cancer 2015;88:167-73.

42. Teh E, Abah U, Church D, et al. What is the extent of the advantage of video-assisted thoracoscopic surgical resection over thoracotomy in terms of delivery of adjuvant chemotherapy following non-small-cell lung cancer resection? Interact Cardiovasc Thorac Surg 2014;19:656-60.

43. Shukuya T, Takahashi T, Tamiya A, et al. Evaluation of the safety and compliance of 3 -week cycles of vinorelbine on days 1 and 8 and cisplatin on day 1 as adjuvant chemotherapy in Japanese patients with completely resected pathological stage IB to IIIA non-small cell lung cancer: a retrospective study. Jpn J Clin Oncol 2009;39:158-62.

44. Wang BY, Huang JY, Hung WH, et al. Impact on Survival on Interval between Surgery and Adjuvant Chemotherapy in Completely Resected Stage IB-IIIA Lung Cancer. PLoS One 2016;11:e0163809.

45. Pepe C, Hasan B, Winton TL, et al. Adjuvant vinorelbine and cisplatin in elderly patients: National Cancer Institute of Canada and Intergroup Study JBR.10. J Clin Oncol 2007;25:1553-61.

46. Früh M, Rolland E, Pignon JP, et al. Pooled analysis of the effect of age on adjuvant cisplatin-based chemotherapy for completely resected non-small-cell lung cancer. J Clin Oncol 2008;26:3573-81.

47. Booth CM, Shepherd FA, Peng Y, et al. Adoption of adjuvant chemotherapy for non-small-cell lung cancer: a population-based outcomes study. J Clin Oncol 2010;28:3472-8.

48. Cuffe S, Booth CM, Peng Y, et al. Adjuvant chemotherapy for non-small-cell lung cancer in the elderly: a population-based study in Ontario, Canada. J Clin Oncol 2012;30:1813-21.

49. Ganti AK, Williams CD, Gajra A, et al. Effect of age on the efficacy of adjuvant chemotherapy for resected nonsmall cell lung cancer. Cancer 2015;121:2578-85.

50. Berry MF, Coleman BK, Curtis LH, et al. Benefit of adjuvant chemotherapy after resection of stage II (T12N1M0) non-small cell lung cancer in elderly patients. Ann Surg Oncol 2015;22:642-8.

51. Lin ZZ, Shau WY, Shao YY, et al. Survival following surgery with or without adjuvant chemotherapy for stage I-IIIA non-small cell lung cancer: an east asian populationbased study. Oncologist 2012;17:1294-302.

52. Kankesan J, Shepherd FA, Peng Y, et al. Factors associated with referral to medical oncology and subsequent use of adjuvant chemotherapy for non-small-cell lung cancer: a 
population-based study. Curr Oncol 2013;20:30-7.

53. Wisnivesky JP, Smith CB, Packer S, et al. Survival and risk of adverse events in older patients receiving postoperative adjuvant chemotherapy for resected stages II-IIIA lung cancer: observational cohort study. BMJ 2011;343:d4013.

54. Batum O, Anar C, Özdoğan Y, et al. Use of adjuvant chemotherapy for nonsmall cell lung cancer: Is advanced age a prognostic factor? Indian J Cancer 2018;55:282-7.

55. Park S, Kim IR, Baek KK, et al. Prospective analysis of quality of life in elderly patients treated with adjuvant chemotherapy for non-small-cell lung cancer. Ann Oncol 2013;24:1630-9.

56. Gridelli C, Balducci L, Ciardiello F, et al. Treatment of Elderly Patients With Non-Small-Cell Lung Cancer: Results of an International Expert Panel Meeting of the Italian Association of Thoracic Oncology. Clin Lung Cancer 2015;16:325-33.

57. Poudel A, Sinha S, Gajra A. Navigating the Challenges of Adjuvant Chemotherapy in Older Patients with EarlyStage Non-Small-Cell Lung Cancer. Drugs Aging 2016;33:223-32.

58. Blanco R, Maestu I, de la Torre MG, et al. A review of the management of elderly patients with non-small-cell lung cancer. Ann Oncol 2015;26:451-63.

59. Veluswamy RR, Levy B, Wisnivesky JP. Chemotherapy in elderly patients with nonsmall cell lung cancer. Curr Opin Pulm Med 2016;22:336-43.

60. Remon J, Lianes P, Martínez S, et al. Adjuvant treatment in resected non-small cell lung cancer: current and future issues. Crit Rev Oncol Hematol 2013;88:375-86.

61. Gajra A. Adjuvant chemotherapy in older adults with nonsmall cell lung cancer. Am Soc Clin Oncol Educ Book 2013. doi: 10.1200/EdBook_AM.2013.33.e185.

62. Booth CM, Shepherd FA, Peng Y, et al. Adjuvant chemotherapy for non-small cell lung cancer: practice patterns and outcomes in the general population of Ontario, Canada. J Thorac Oncol 2012;7:559-66.

63. Aljubran A, Leighl N, Pintilie M, et al. Improved compliance with adjuvant vinorelbine and cisplatin in nonsmall cell lung cancer. Hematol Oncol Stem Cell Ther 2009;2:265-71.

64. Kenmotsu H, Ohde Y, Wakuda K, et al. Survival data for postoperative adjuvant chemotherapy comprising cisplatin plus vinorelbine after complete resection of nonsmall cell lung cancer. Cancer Chemother Pharmacol 2017;80:609-14.

65. Kenmotsu H, Ohde Y, Shukuya T, et al. Feasibility of postoperative adjuvant chemotherapy of cisplatin plus vinorelbine for completely resected non-small-cell lung cancer: a retrospective study in Japan. Respir Investig 2012;50:157-61.

66. Williams CD, Gajra A, Ganti AK, et al. Use and impact of adjuvant chemotherapy in patients with resected non-small cell lung cancer. Cancer 2014;120:1939-47.

67. Paull DE, Thomas ML, Meade GE, et al. Determinants of quality of life in patients following pulmonary resection for lung cancer. Am J Surg 2006;192:565-71.

68. Couillard-Montminy V, Gagnon PY, Fortin S, et al. Effectiveness of adjuvant carboplatin-based chemotherapy compared to cisplatin in non-small cell lung cancer. J Oncol Pharm Pract 2019;25:44-51.

69. Custodio Carretero AB, García Sáenz JA, González Larriba JL, et al. Adjuvant chemotherapy for early-stage non-small-cell lung cancer. Single-centre experience and literature review. Clin Transl Oncol 2008;10:560-71.

70. Chang WJ, Sun JM, Lee JY, et al. A retrospective comparison of adjuvant chemotherapeutic regimens for non-small cell lung cancer (NSCLC): paclitaxel plus carboplatin versus vinorelbine plus cisplatin. Lung Cancer 2014;84:51-5.

71. Morgensztern D, Samson PS, Waqar SN, et al. Early Mortality in Patients Undergoing Adjuvant Chemotherapy for Non-Small Cell Lung Cancer. J Thorac Oncol 2018;13:543-9.

72. Bezjak A, Lee CW, Ding K, et al. Quality-of-life outcomes for adjuvant chemotherapy in early-stage non-small-cell lung cancer: results from a randomized trial, JBR.10. J Clin Oncol 2008;26:5052-9.

73. Rodríguez M, Ajona D, Seijo LM, et al. Molecular biomarkers in early stage lung cancer. Transl Lung Cancer Res 2021;10:1165-85.

74. Wakelee HA, Altorki NK, Zhou C, et al. IMpower010: Primary results of a phase III global study of atezolizumab versus best supportive care after adjuvant chemotherapy in resected stage IB-IIIA non-small cell lung cancer (NSCLC). J Clin Oncol 2021;39:abstr 8500.

75. Wu YL, Tsuboi M, He J, et al. Osimertinib in Resected EGFR-Mutated Non-Small-Cell Lung Cancer. N Engl J Med 2020;383:1711-23.

Cite this article as: Desage $\mathrm{AL}$, Bouleftour $\mathrm{W}$, Tiffet $\mathrm{O}$, Fournel P, Tissot C. Use of adjuvant chemotherapy in resected non-small cell lung cancer in real-life practice: a systematic review of literature. Transl Lung Cancer Res 2021;10(12):4643 4665. doi: 10.21037/tlcr-21-557 